\title{
Foundations of Interreligious Learning from an Islamic Perspective
}

\section{Introduction}

Interreligious collaboration in religious education is a young field of research that has been gaining significance in recent decades in German-speaking areas. Interreligious approaches in educational contexts began in close conjunction with the increasing religious and worldview pluralisation of society. The constant increase in labour migration in German-speaking areas since the 1960s and 1970s led to intense discussions on how to do deal with non-Christian religions in the schools (Hellmann, 2000, 1f.; Auernheimer, 1990). These processes were also reflected in religious educational approaches in German-speaking areas, especially the countries of Austria and Germany. Our regional focus in this essay on these German-speaking areas is based on the principle of confessionalism that characterises religious education in German-speaking countries (Lüdtke \& Pohl-Patalong, 2018; Lehner-Hartmann, 2020). This principle means that the officially recognised religious communities are charged with the task of giving confessional religious education at elementary and secondary schools and issuing a curriculum, and they are given the right to supervise and direct religious education and to appoint religion teachers. The state's role in religious education is limited to school organisation and discipline. The education of the religion teachers is generally done at officially recognised colleges or universities. Thus, interreligious collaboration in religious education at schools constitutes a particular challenge for German-speaking countries with their confessional religious education.

Consequently, approaches to interreligious collaboration in general and models for interreligious learning in religious educational contexts are the subject of intense discussion. Interreligious learning is understood below as forms of collaboration between various religious communities or confessions. This collaboration is concerned with the transmission, exchange, or appropriation of knowledge about different religions and the religious other in the school context and are oriented to standards of educational science (Schweitzer, 2015, 2f.). Interreligious collaboration can thereby mean various things. For example, various religious denominations can participate in the development of curricula, teachers from various faiths can transmit the content, or pupils from various faiths can take part in the teaching formats.

Again, interreligious learning is a matter of developing religious competences in connection with

Ә OpenAccess. ( 2022 Zekirija Sejdini, published by De Gruyter. (cc) BY-NC-ND This work is licensed under the Creative Commons Attribution-NonCommercial-NoDerivatives 4.0 International License. 
intentionally controlled pedagogical processes in which spaces for encounter with religious testimonies are introduced whose religious background is differently constituted than that of the students and is based on a constructive encounter with and respect for the other. (Meyer, 2019, 19f.)

The goal of interreligious learning is thus to have students look at their religion not only from the perspective of their own faith, as in the classical confessional or 'monoreligious' educational form, but also to include the perspective of other religions or those who have different beliefs (Van der Ven \& Ziebertz, 1995, 264).

In recent decades, a plurality of various approaches to interreligious collaboration in religious-educational contexts has developed. In large part, these are related to the interplay between Christianity and Islam. Some of these approaches in which Christian and Islamic perspectives are related to each other are focused on theory while others are more strongly oriented to application (Kraml, Sejdini, Bauer \& Kolb, 2020, 32-37; Kolb, 2021b). The approaches that have been developed, however, seldom define the anthropological and theological foundations and the understanding of education that are necessary to shape processes of interreligious education in an explicit way. Instead, most common approaches to interreligious education are dominated by the educational and didactic perspectives or by the socio-political relevance of such collaboration.

This finding applies in particular to Islamic perspectives, for, in developing interreligious collaboration, little attention has been paid until now to Islamic foundations. Muslim theologians and religious educationists also participate insufficiently in the conceptualisation and implementation of interreligious collaboration in German-speaking areas. The reasons for this may be completely comprehensible, but that does not change the fact that there is a certain asymmetry in this area that affects the conceptualisation of interreligious education. The purpose of this essay is therefore to close these gaps and outline basic building blocks for interreligious learning from an Islamic perspective that can serve as foundations for interreligious collaboration in religious educational contexts. Existing interreligious approaches can be developed further on this basis.

Before we turn to the Islamic basic building blocks for interreligious education, I will first give an overview of the state of research and the range of interreligious collaboration and approaches to interreligious learning in Germanspeaking areas. Subsequently, in connection with that, I will explain Islamic perspectives on forms of interreligious education. The next section will address anthropological foundations and the understanding of both theology and education from an Islamic perspective. In the discussion following that I will focus on various anthropological, theological, and educational implications for interreligious collaboration. Finally, the conclusion will present reflections that con- 
tain ideas and perspectives for the further development of interreligious collaboration in religious educational contexts.

\section{Interreligious Collaboration and Approaches to Interreligious Learning in Religious Education: An Overview of the State of Research}

I will first provide an overview in this section of the state of research on interreligious collaboration and approaches to interreligious learning in German-speaking countries. ${ }^{1}$ In the presentation of this research I will draw attention to the problem of asymmetry with respect to religion in the development of interreligious approaches: aside from a few exceptions, which will be explained more precisely below, the forms of interreligious collaboration and approaches to interreligious learning have until now been developed almost exclusively from the Christian side.

In relation to interreligious education and learning in religious educational contexts, various approaches on the elementary level (Fischer, 2005; Linger-Ali \& Mecheril, 2016; Boll, 2017), on the secondary (Leimgruber, 2005, 2007; Behr, 2017; Grümme, 2017), and tertiary levels (Haußmann, 2005; Baumann, 2005; Simojoki \& Lindner, 2020) have been developed. One focus here raises the question of how, under what circumstances, the encounter with the religious other can take place. There are various proposals available here: the xenosophical religious didactics approach (Streib, 2005), the double individual recourse model (Meyer, 2019), the difference-sensitivity approach (Peter, 2015), and the understanding of interreligious learning as a passage through the unfamiliar (Tautz, 2007, 2017).

In addition to these rather theoretically oriented approaches, there are also cases of interreligious collaboration that are used in educational praxis in secondary and tertiary education. A preliminary approach, which grapples empirically with the implementation of an interreligious educational project, came from Friedrich Schweitzer, Magda Bräuer, and Reinhold Boschki (2017). Developed at the University of Tübingen (Germany), this approach is concerned with the learning outcomes and the effectiveness of interreligious learning, the extent to which, for example, adoption of another religious perspective as a re-

1 Here I sketch interreligious approaches in which Christian and Islamic perspectives play a role. Approaches that focus on other religions cannot be treated here. 
sult of interreligious teaching units can be ascertained in business schools (Schweitzer, Bräuer \& Losert, 2017, 24).

Another instance of collaboration is the approach of the interreligious encounter learning developed by Katja Boehme (Heidelberg, Germany). In this approach pupils first work on a theme in their religion classes from the perspective of their subjects. Following that, the second step involves interreligious encounters on project days with pupils from other faiths. In a third step, the pupils exchange ideas on the themes they have worked on in mixed groups (Boehme, 2017; 2018; 2020).

The research group led by Jan Woppowa in Paderborn (Germany) (Woppowa, 2016) also looks at difference-sensitivity possibilities of interreligious collaboration in confessional religious education. Religious education connected with a specific religion is supplemented by interreligious encounter learning in several phases (Woppowa, Caruso, Konsek \& Kamcili-Yildiz, 2020, 375). With his approach of dialogical interreligious learning, Thorsten Knauth (Duisburg-Essen) also tackles interreligious collaboration in religious education in confessional contexts (Knauth, 2019). This approach has students from various religious backgrounds take religious education together and learn from each other in joint discussions (Knauth, 2016, 7; 2020).

Other approaches to interreligious collaboration deal with tertiary education. Here we can mention the approaches of the research group led by the religious educationist Wolfgang Weirer in Graz (Austria) (Weirer, Wenig \& Yagdi, 2019; Gmoser \& Weirer, 2019) as well as interreligious encounter learning in the education of religion teachers at the University College of Teacher Education of Christian Churches Vienna/Krems (Kirchliche Pädagogische Hochschule Wien/Krems, KPH, Austria) (Garcia Sobreira-Majer, Abuzahra, Hafez \& Ritzer, 2014; Garcia Sobreira-Majer, 2015; Boehme \& Krobath, 2020; Krobath, 2020).

Finally, we can point to interreligious collaboration at the University of Innsbruck (Austria), which is carried out in the education and training of Islamic and Catholic religion teachers. Encounters with the religious other occur within the framework of practicums and courses. In line with the parity principle, the supervision of the courses is carried out by a mixed team of instructors, and Catholic and Muslim students take part together (Kraml \& Sejdini, 2018; Kraml, Sejdini, Bauer \& Kolb, 2020, 86-89). The interreligious collaboration includes not only collaboration in the education and training of religion teachers but also a common understanding of theological and anthropological basic assumptions from various religious perspectives (Sejdini, Kraml \& Scharer, 2020).

If we look at the state of research, two tendencies emerge that characterise existing approaches to interreligious learning and interreligious collaboration. On the one hand, it is striking that these are almost exclusively conceived and 
developed by Christian religious educationists. As a result, there is an asymmetry in these approaches: and they are dominated by the perspective of a specific religion. Generally speaking, Islamic perspectives are granted only subordinate significance; they remain underexposed or are left out of consideration. Only in a few exceptions - such as in the interreligious collaboration in Innsbruck - does the Islamic perspective form, in the sense of the parity principle, a constitutive part of the interreligious approach right from the start (Kolb, 2021b). We can therefore claim that interreligious collaboration and approaches to interreligious learning from an Islamic perspective need to be thoroughly substantiated.

This overview of the existing approaches, on the other hand, shows that the questions about the anthropological, theological, and educational foundations of the perspectives of the participant religious groups that would be necessary to make interreligious learning possible receive little attention. In contrast, the pedagogical or educational perspectives are dominant. Here we are arguing that, in addition to focusing the approaches to interreligious learning on educational points of view, it is of major importance that the Islamic concept of humanity and the Islamic understanding of theology and education be taken equally into account.

In the next section, I will therefore first formulate Islamic perspectives on interreligious collaboration and concepts of interreligious learning. In the section after that, I will then focus on Islamic foundations relating to anthropology, theology, and the understanding of education.

\section{Interreligious Collaboration from an Islamic Perspective}

From an Islamic perspective, there are various reasons that justify interreligious collaboration and interreligious learning. In addition to socio-political relevance, such collaboration appears to be theologically inevitable as well. This is so, above all, because Islam sees itself as part of or the completion of the monotheistic tradition. In the Qur'an, the chief source of Islam, there are numerous verses that point to and emphasise the common origin of Judaism, Christianity, and Islam (Q 2:136; 3:64; 3:84; 5:48). The intention of the Qur'an to persuade the people of the book - as Jews and Christians in the Qur'an are called - of their common origin cannot be overlooked. From an Islamic point of view, Moses, Jesus, and Muhammad are messengers of the same God who is revealed in the Torah, the Bible, and the Qur'an.

The reference to the monotheistic tradition has led inevitably to Judaism and Christianity being dealt with more intensively than any other religion in the Qur'an. This is a spirited and ambivalent discourse that extends throughout 
the entire Qur'an. The encounter is spirited because it concerns itself above all with the beliefs of Jews and Christians whom Muslims saw every day; and it is ambivalent because it is conditioned by the situation. The Qur'anic statements on Judaism and Christianity are dispersed throughout the whole Qur'an and are dependent on their respective contexts of revelation.

The fact that the Qur'an was revealed over a period of 23 years and is not arranged either thematically or chronologically has led to different interpretations. Over the course of time, Muslim scholars developed various approaches to the people of the book. In addition to the approach the respective scholars had to the Islamic sources, especially the Qur'an, these approaches were influenced decisively by the socio-political situation in which these concepts were formed. The dependence of these approaches on their context led to the former approaches being focused primarily on the question of salvation and the legal status of Jews and Christians in Muslim-majority societies. These approaches have retained historical value right up to the present because they provide information on how Muslims in the past dealt with these questions theologically. For the current context, however, especially interreligious learning, they are of only limited value - if at all. In addition to the many different interpretative possibilities and approaches, what is of decisive importance for interreligious learning from the Muslim perspective is that, on the one hand, the Qur'an explicitly prohibits any sweeping judgments being made of Jews or Christians (Q 3:75; 3:113); on the other hand, it does not exclude them from the possibility of salvation (Q 2:62). Reference is made at this point to the fact that Qur'anic statements are in no way purely exclusivist but also include inclusivist and pluralist positions (Pink, 2011). ${ }^{2}$ For interreligious learning, the willingness to not exclude others from salvation is of enormous significance and an important sign of esteem, without which the processes of education have little chance of bearing fruit.

Despite this enormous significance, however, this field has until now not received the required attention it needs to shape interreligious education in an expedient way. Because of that, we will look below at the theological and religiouspedagogical foundations that are necessary for designing a stable basis for processes of interreligious education. Here we are concerned with basic principles whose absence would condemn any deep mutual learning in the interreligious context to superficiality.

Because the human being is at the centre of interreligious education, an analysis of the question of an appropriate concept of humanity as an important

2 For an extended discussion of this question see also the essay 'Religious Plurality from the Perspective of Islamic Religious Education' in this volume. 
foundation for interreligious learning seems inevitable. Whether the Qur'an contains the anthropological foundations to develop a concept of humanity that can be used for interreligious education and how this concept of humanity can be developed will be determined below.

\section{Foundations of the Processes of Interreligious Education}

This essay is intended to sketch, from the Islamic perspective, the basic building blocks of interreligious learning that can serve as a foundation for interreligious collaboration in contexts of religious-educational contexts. There are three areas here that are to be emphasised individually: (4.1) basic anthropological questions, (4.2) the understanding of theology, and (4.3) the understanding of education. We should keep in mind that this division does not claim to be exhaustive, and hence it can be expanded or deepened as needed.

\subsection{Basic Anthropological Issues}

With interreligious work in educational contexts, some understanding of basic anthropological questions is needed to make substantive interreligious learning possible. In particular, the urgency of this consists first in the question whether interreligious collaboration in which the various faith communities participate as equals should occur at all. The second issue regarding its urgency is whether it is to be directed at learning about and from others and expanding one's own horizon.

Educational processes are stamped to a particular degree by concepts of humanity. Every educational approach is based on a certain concept of humanity. The orientation to this is important to the extent that a specific understanding of education can be developed through it in which adolescents can form their subjectivity. Only as the result of such can a conception be developed of how people can be led, through upbringing or education, to develop a self-understanding that corresponds to this concept of humanity (Ribolits, 2015, 170).

The religious conceptions of humanity are based above all on religious sources. In Islam, the foundations for such conceptions are found in theological sources, especially the primary source, the Qur'an, and the secondary source, the Sunnah. That is where we find the ambivalent statements on aspects of the concept of humanity that permit several options. This led to different and multifaceted concepts of humanity among Muslims, even though the religious sources are the same. The reason for this lies in the fact that perspectivity and 
contextuality constantly play an important role when it concerns the interpretation of anthropological statements in the theological sources.

In the substantive determination of anthropological foundations, a connectedness with the Muslim tradition is to be preserved and concepts of humanity to be derived from the Islamic sources that can be connected to interreligious collaboration and approaches to interreligious learning. The following analysis is focused here on various features that are found in the Islamic sources and in the view of many scholars: human dignity and createdness (4.1.1), freedom and responsibility (4.1.2), and reason and learning (4.1.3). Conclusions can be drawn from this for interreligious education.

\subsubsection{Dignity and Createdness}

There are various passages in the Qur'an that point to an inviolable and Godgiven dignity of the human being. The most important direct reference is found in Q 17:70. Here dignity is described as one of the most fundamental properties of the human being, which is inalienable and should not be violated (Albayrak, 2019, $114 \mathrm{f}$.). The relevance of these verses lies in the fact that dignity not only belongs to Muslims but to all people. Ethnicity, race, gender, and faith or religion play no role here (Sejdini, 2016a, 22). Mohamed Talbi infers from that fact that: "We can also assume that all people are truly equal on the level of the spirit, whatever their physical and mental abilities may be" (Talbi, 1993, 57).

In addition to this direct reference to the inviolable God-given dignity of the human being, other verses in the Qur'an point to the special care God took in the creation of human beings (Q 55:10-14; 67:23). The Qur'an unmistakably underscores that a central role has been granted to human beings in creation. They are the viceregent of God on earth, which allows human beings "to get to know the universe, to reflect on existence, to name things, produce knowledge, and create culture" (Albayrak, 2019, 113).

Another fundamental anthropological feature that characterises the Islamic concept of humanity is the human being's createdness. According to the Qur'an, the human being, like all other creatures, is called into life by God (Q 16:4). He/ she was created out of matter, which exists independently of and before him/her. The human being owes her/his existence not to her-/himself or to chance but to a higher entity who is independent of all things and whose existence depends on no one.

The connection of the human species to its creator represents, from the Islamic point of view, an important anthropological principle. The human being had gone through several developmental stages (Q 15:26; 32:7; 76:1-2; 96:2) before she/he became human through the divine spirit being breathed into her/ 
him (Q 15:29; 32:9; 38:72). This act filled the material form with life and gave humans the potential to acknowledge the existence of God and to be devoted to God ( $Q$ 30:30). It is that that constitutes the nature or disposition of the human being (fitra). Through having the spirit breathed into him/her, the human being is transformed from a damp clay paste into a spiritual being equipped with the divine spirit and with mental and spiritual abilities (Hajatpour, 2014, 79).

The dignity and createdness of the human being are closely connected with the human's special properties and abilities that are bestowed up her/him at creation. This includes freedom and responsibility, which will be discussed in the next section.

\subsubsection{Freedom and Responsibility}

Human freedom is a recurring and controversial topic in Islamic theological debates (Wielandt, 1994, 101-103). This coheres above all with the fact that the Qur'an contains both statements that acknowledge the freedom of human beings (Q 6:164) and verses that give the impression that human beings are only doing what they are predestined to do (Q 9:51; 57:22).

Generally speaking, contemporary analyses represent the position that the Qur'an as a whole supports the principle of freedom and of free will as a fundamental human disposition. Here the argument is that a position that advocates that the human being is determined in all aspects of her/his life contradicts the principle of human dignity (Sejdini, Kraml \& Scharer, 2020, 56). The human being's potential for development and change to which the Qur'an refers in various places is excluded in a deterministic concept of humankind. In principle, therefore, freedom can be understood from the perspective of Islamic theology as an essential property of the human being, which also distinguishes him/her from other beings and creatures. Freedom is thus characterised by an ambivalent character for it can lead to either well-being or disaster (Q 2:30).

There are limits to human freedom, however. Humans are not able to overcome the conditions of existence that were created for them or into which they were born. It is impossible for human beings to move into a different sphere of existence. Nonetheless, humans can act autonomously, however, in relation to their will, their decisions, their preferences, and actions (Albayrak, 2019, 113). Their free will includes the freedom to decide for or against God, to join a religion of their choice or to leave a religious community (Q 2:256; 18:29). In this connection as well, the Qur'an displays a pluralist approach to dissenters and other religious communities. 
Closely connected with the principle of freedom is the responsibility that God has bestowed on the human species for itself and its environment and that the human species is always to meet. It can be concluded from the Qur'an that the human being has to assume individual responsibility. That cannot be shoved off onto a third party or God (Q 17:15; 35:18). Each person is responsible for one's own deeds and will give account of them in the afterlife (Q 67:2).

From an Islamic theological perspective, the human being has a special responsibility within creation. The world has been created in such a way that the human being can make use of it. Creation is not, however, at the unlimited disposal of humans, which they use as they see fit and without any consideration for its good; rather, creation is entrusted to them (Q 33:72). The concept of entrusting (amana) creation to humans indicates that it is not meant to be their eternal possession but at their temporarily limited disposal that includes a special responsibility (Sejdini, 2016b, 297f.).

The human being is, moreover, summoned to care for creation so that justice is done to God's entrusting of creation to humans. God does give human beings a temporarily limited charge over creation but expects them to engage in this task in a responsible and careful way, and in the end they will have to answer for this (ibid., 298). This careful dealing with the world can be related both to the environment and nature as well as to groups and adherents of other religions or ethnic groups.

Freedom and responsibility are also closely related to other anthropological properties. Especially emphasised in the religious educational context are the gift of reason and the ability to learn, which we will look at briefly in the next section.

\subsubsection{Reason and the Ability to Learn}

The gift of reason and the ability to learn are central anthropological features that distinguish the Islamic concept of humanity. The Qur'an says that God forms the human being according to his will already in the mother's womb and gives him cognitive aptitudes, the ability to know, and reason ( $Q$ 16:78). The human being is given the ability to think, to understand, to know, and to draw logical conclusions (Q 39:9). The Qur'an indicates, moreover, that faith and reason are in no way opposed to each other but that the way to divine salvation proceeds via the use of reason (Q 38:29). It is only because of that that human beings can be addressed by the divine message, to recognise it, and to respond to it.

The human being is summoned elsewhere to explore his/her environment, to engage in communication with other people, and to aspire to new knowledge 
that can again be put to the service of humanity (Q 6:32). In other words, the Qur'an repeatedly demands people use their reason to develop themselves and the world. Conversely, those who do not use their reason to reflect are reprimanded (Q 8:22; 10:100).

As already mentioned elsewhere, the Qur'an indicates that human beings have inclinations and drives like egoism, greed, impatience, or ingratitude that know no limits and can have negative consequences in social contexts (Q 14:34; 21:37; 59:9). Human reason and the description of humans as beings capable of learning (Q 96:1) is thus accorded an existential role that can be developed via upbringing, socialisation, and education. Muhammad Asad points out in his commentary that human reason also leads to the ability to accumulate knowledge and to gain insight and understanding "that the individual human being does not know on his own" (Asad, 2017, 1175). This clarifies the importance of this fundamental anthropological position for interreligious learning.

From the above, we can conclude that, from a Qur'anic perspective, human beings are creatures who have dignity bestowed on them and are open to change and further development. They can choose to move in the direction of good or bad (Albayrak, 2019, 112). Internal and external factors are decisive for development in a certain direction. That is why human beings need (religious) education - so that they can develop themselves in the direction of the good and to arrive at the phase of the cultivation of the self (Jensen, 1990, 205).

This anthropological approach presupposes that all people are equal because of their humanity, as creatures who are indeed dependent on their creator. But because of their special position, they are equipped with abilities and skills like reason, freedom, and the ability to learn - that distinguish them from other creatures. Such an approach provides a solid basis for respectful interreligious approaches stamped by mutual inspiration.

In addition to a suitable concept of humanity, a process of interreligious education also requires an understanding of theology that, as a partner science of religious education, has enormous significance for the shape of interreligious education. Just as with the concept of humanity, so it is also necessary to explain which understanding of theology is needed to make the processes of interreligious education fruitful.

\subsection{The Understanding of Theology}

When situating religious education as a discipline, we encounter two different tendencies. The one is more strongly oriented to religious studies and considers, in addition to the educational sciences, religious studies to be the partner 
discipline of religious education. The other tendency is confessional in nature and views theology as the reference field of study of religious education. Working from this, Michael Grimmitt distinguished between learning "in religion" as learning from the internal perspective of religion, and "from religion" or "about religion" (Grimmitt, 1981, 42-53) as learning from the external perspective. Because - aside from a few exceptions - the confessional type of religious education is established practice in German-speaking areas, theology is the most important partner science of religious education along with educational science. As such, the understanding of theology is of enormous importance for religious education, especially when it concerns processes of interreligious learning. Therefore, we will briefly look at what understanding of theology is needed to promote interreligious education.

Here, the first question is what theology adds specifically. In connection with this, people often think of a purely material understanding centred on content. That is, the theological is viewed as a clearly delimitable and explicitly religious field of study, as, for example, beliefs, explicit theological concepts, religious rites, actions of the religious community, etc. From the point of view of an experience-oriented religious pedagogy and for interreligious education, such an understanding falls short. For this, the nature of the theological is more a matter of the perspective from which something is examined and cannot be reduced to the material object.

For interreligious learning, two aspects are especially important with respect to Islamic theology. First is the awareness that theology, as God-talk, cannot have any claim to absolute congruity with its central theme. This is so, on the one hand, because God is beyond human control and no one other than God himself can speak in a suitable way about God. On the other hand, it is also because human beings by nature have no direct access to truth, and therefore their knowledge is always perspectival and fragmentary. Second, it is necessary to distinguish between personal faith and Islam with its doctrines, rituals, and traditions. Even if faith is influenced by theological reflection, as a personal act it remains more or less inaccessible to theology. That is why, in an academically situated theology, it can never be a matter of leading people to faith or converting them through propaganda, but one of critical reflection and appropriate interpretations of one's own religious tradition.

In principle, theology is to be understood here as an academic discipline or science that cannot count on a 'sure ground'. It should not take the place of truths of faith, and knowledge should only be thought of as such provisionally. In this sense, theology could be characterised more as having a questioning scientific character and - similar to Fritz Simon's formulation - as aware that knowledge limits one's sense of possibilities (Simon, 1999, 133, 157). Despite 
all these peculiarities, subjectivity, and provisionality, however, theology is equally challenged to retain an academic and scientific character above all in the sense of transparency and the intersubjective verifiability of insights and results (Schärtl, 2004, 164).

This understanding of theology provides a solid foundation for processes of interreligious education. The awareness that God transcends every theological presentation and that speaking of God is always just one perspective among many also grants a certain validity to other theological approaches. This again is essential in initiating interreligious learning processes that are open to learning from each other and to appreciating other approaches. Moreover, the focus of such an understanding is more on presenting one's own experiences intelligibly and being inspired by similar efforts and not on leading other people to faith or conversion. For Islamic theology, this means:

to explain in an academic setting ... the rationality and intellectual comprehensibility of the Islamic faith again and again in accordance with the horizon of the temporal experience of the present (Sanseverino, 2016, 174).

In addition to the concept of humanity and understanding of theology, another aspect of fundamental importance for interreligious learning is the understanding of education. The success of processes of interreligious education is decisively dependent on which understanding of education is being worked with. That is why we will discuss this briefly in the next section.

\subsection{The Understanding of Education}

Alongside anthropology and theology, the understanding of education is another important foundation for the processes of interreligious education. Here the question arises as to how education is to be understood in interreligious learning so that mutual learning is at all possible.

From an Islamic perspective, it is impossible to analyse the understanding of education without taking the Qur'an into account. The Qur'an is the foundation of Islamic religious education and also takes up the theme of education in various places. ${ }^{3}$ Like all other themes, education is not dealt with systematically in the Qur'an. This is - as already stated above - due to the circumstances of how it came into being. A positive attitude to education can be found in the Qur'an in

3 If education is spoken of in general in the theological sources (the Qur'an and the Sunnah), religious education is also generally thematised or intended. 
central statements. A special symbolic significance can be accorded to the first revealed verses of the Qur'an in this respect. These verses sent to the prophet $\mathrm{Mu}$ hammad in $610 \mathrm{AD}$ begin with the call Iqra, by which Muhammad is called to read or recite. We read:

READ in the name of thy Sustainer, who has created man out of a germ-cell! Read - for thy Sustainer is the Most Bountiful One who has taught (man) the use of the pen, taught man what he did not know! (Q 96:1-5)

Given the circumstances under which these verses were revealed, a simple interpretation of the call issued to the prophet cannot be established. Nevertheless, the passage cited is often understood as a call to all Muslims to educate themselves and to engage in self-development. This process of education implies a reflection on the entire creation, which is to enable human beings to know themselves, their surroundings, and their environment and to constantly develop themselves both spiritually and intellectually. In addition, there is a series of other Qur'anic statements that emphasise the importance of education in an indirect way (Q 2:266; 10:24; 13:3; 16:11; 30:21). They give expression to an affirmative attitude towards education.

As in the Qur'an, the theme of education is also treated in the vast traditions of the Sunnah that are called hadith in a plurality of contexts. The connotations of the theme are largely positive. The affirmative attitude towards education in the Sunnah is shown below by means of select examples. An important, very well-known hadith is that tradition in which striving for knowledge is viewed as a religious obligation ( $f a r d$ ) (Ibn Māğa, 1998, 214f.). This reading is supported by a second tradition in which Muslims are called to strive for knowledge and to acquire this, even if that knowledge is found in China (Al-Hindi, 2005, 1294).

In the Sunnah, education is generally viewed not only as desirable and Muslims are not only urged to acquire knowledge, but training and learning are also highly valued. The path to attaining knowledge - in other words, teaching and learning processes - have an important significance. One hadith from the collection of Muslim emphasises the importance of processes of acquiring knowledge: "for whoever follows the path of desiring knowledge, Allah makes the path to paradise easier” (Ibn al-Hağǧāğ, 2006, 1242). The sources mentioned were used for centuries by Muslim scholars as evidence of the importance of education and as a foundation to develop various models (Günther, 2016, 54).

Having now looked at which understanding of education can be found in the theological sources and Islamic foundations for anthropology and theology, in the next section we will explore their implications for interreligious learning and interreligious collaboration. 


\section{Implications for Interreligious Collaboration and Approaches to Interreligious Learning}

As already stated, there is a plurality of approaches to interreligious collaboration in German-speaking countries, each of which have their own focus on the theoretical orientation or the practical application in contexts of religious education. With a view to the existing approaches, it can be asserted that there is a need on the one hand to examine Islamic perspectives more deeply so that approaches to interreligious learning can be solidly grounded in the sense of a dialogue between equals. On the other hand, it turns out that basic anthropological foundations and the understanding of theology and education of the participating religious partners in general and Islamic perspectives in particular play only a secondary role. This contribution takes the position that processes of interreligious education have a chance at success only if concepts of humanity and understandings of theology and education are sufficiently clarified and reflected upon so that they can serve as a foundation for respectful interreligious learning. Moreover, an interreligious learning that is mutually inspiring and oriented to learning from each other needs an understanding of theology and education that is accessible and open to the other and not just viewed as a closed system.

In particular, I will here bring the basic Islamic anthropological positions and the understanding of Islamic theology and education to bear on the conceptions of interreligious approaches. I will then present some stimuli for interreligious collaboration and interreligious learning in anthropological and theological respects as well as in relation to educational perspectives.

With respect to anthropology, according to the insights afforded by the Islamic concept of humanity, the following implications for the processes of interreligious learning can be drawn.

- The embedding of the God-given and inviolable dignity of human being in Islamic anthropology is a central starting point for interreligious learning and collaboration. The inalienability of universal dignity - independent of gender, age, race, or religious affiliation - constitutes the most important foundation for grounding interreligious approaches from an Islamic perspective. The assumption of inviolable universal God-given dignity paves the way for viewing others as equal; the success of interreligious learning depends on this. This may sound trivial at first because the acknowledgement of others is self-evident. Closer examination reveals, however, that this is often not the case, even if it is not explicitly stated. Acknowledging the equality of others is indispensable for interreligious learning primarily because it relativises claims of superiority that have emerged over time through characteristics, attributions, and affiliations and thus makes learning with and from others 
easier. It therefore contributes to eliminating asymmetries that form a major obstacle in particular for interreligious learning.

- Closely bound up with that is the consideration of human free will. It is particularly important for interreligious education to constantly keep in view that human beings can freely choose to decide for or against religion. This freedom - precisely like human dignity - is God-given and a characteristic of humanness. Accordingly, Islamic religious education should be cognisant of this freedom and understand faith as an option. Based on human freedom, the religious other should be acknowledged as he/she is and his/her decision respected. This approach, which is based in the Qur'an, opens up the possibility to treat a person's choice for a religion with respect and not to see it as misguided if that choice falls on another religion than one's own. It is not a question here of affirming or accepting the content of another religion but rather of granting to others the option to choose. If one holds that the goal of religious education consists primarily in supporting pupils as they become subjects and their faith unfolds independently so that they develop their own approach to faith, it then becomes clear that this is also of enormous significance for interreligious learning.

- Another aspect is the principle of educational orientation that characterises the Islamic concept of humanity. Equipped with reason, the human being relies on education for continuous self-development. As a creature capable of being educated, the human being is encouraged to use her/his reason to investigate her surroundings and environment and to acquire new insights to do justice to her responsibility for creation. The encounter with the religious other and the productive exchange and learning with and from each other is essential for one's own education. To go through educational processes and this includes interreligious experiences - is thus, from the Islamic perspective, a natural part of human development.

Starting from fundamental Islamic theological positions, we can also formulate the following stimuli for interreligious learning.

- It follows from the discussion until now that human beings do enjoy a central place in creation and are equipped with special abilities and skills, but their ability to gain knowledge, like their existence, is not absolute. According to Islamic theology, everything but God is contingent. Everything can exist but does not need to. Their possible existence, in contrast to what is necessary - i.e., God - depends on a power that transcends them. That is why human knowledge as such is always fragmentary and perspectival. Human beings do not have access to knowledge that is not humanly stamped - which does not mean, however, that such knowledge does not exist. 
The fragmentary character of human knowledge is particularly clear in theology, which is concerned with talk about God, because the absolute, i.e., God, transcends human thought. Thus, God-talk says more about the human being than it does about God. It is a requirement of createdness to respect other approaches to God and to grant to them that they have just as much right to develop their own theological ideas that can be just as insightful and legitimate as one's own. The cultivation of one's own perspectival attitude in epistemology is indispensable for interreligious learning, especially those with a confessional character and a strong connection to theology. On the one hand, this tack makes a conciliatory attitude towards other theological approaches easier; on the other, it prevents the absolutisation of one's own theological doctrines in the awareness that it is not a question of the truth as such. Rather, one is faced with contextually stamped interpretations of the truth that are continually changing. This view impacts the understanding of truth, which plays a central role in interreligious education and should therefore be discussed next.

- Religious truths and truth claims are an important characteristic of most religious communities (Sejdini \& Kraml, 2020). What is particularly central here in interreligious education is what understanding of truth is presented to those of other faiths. The approach to theology sketched above and the concept of humanity make clear that it is legitimate to make a truth claim, but others can do so as well. It is important not to confuse the truth claim with truth as such and to distance oneself from the notion that one possesses the truth. In our context, the claim to be the sole possessor of truth means representing the only true faith. If we made such a claim, it would no longer be possible to respect the spiritual experiences of those of other faiths as possible ways to the truth. But this respect is as such a condition for interreligious truth. Instead of claiming to have sole possession of the truth, it is better for interreligious learning to view ourselves as seekers of truth who are aware that the path to truth is inexhaustible and the perspectives of others unavoidable if we are to make progress and come closer to truth. This basic attitude towards truth makes a respectful attitude to plurality easier, which brings us to another implication.

- Whoever is aware of the finiteness and limitation of human knowledge and the inadequacy of truth is more open to religious and worldview plurality. Here, it is important to understand this plurality not as an artificially created situation that must be overcome but as a constellation that corresponds to creation, i.e., is normal. From the perspective of Islamic theology, religious plurality and social diversity are to be viewed as ordained by God. From this perspective, the Qur'an does not represent any claim to supremacy that lifts 
it and what belongs to it religiously above other faith communities but acknowledges the claim to salvation in other religions to be equal in rank (on this, see also Schmidt-Leukel, 2005, 2019). Accordingly, from a religious educational perspective, it is important to take this claim into account if we are to avoid approaches that assume the superiority of one's own religion or exclude other forms of salvation. This can substantiate religious educational conceptions that are aimed at the development of a capacity for plurality or interreligious approaches that are oriented to religiously heterogeneous students or to social heterogeneity.

Finally, there are still implications to be drawn from the Islamic understanding of education. Here as well, other stimuli for interreligious learning and interreligious collaboration can be inferred.

- A first implication for interreligious learning that can be concluded from the Islamic understanding of education is the process character of education. Education is understood in the Islamic perspective as a permanent process to which human beings are called. They are called to educate themselves constantly and to discover the new. In this sense, education is also to be seen as a contribution to personal development that reinforces the self-confidence of younger people and enables them to trust their convictions and to stand by them. From an Islamic perspective, education can neither be closed nor happen in isolation. It requires an exchange, also with the unusual or the new. Accordingly, people are constantly encouraged to encounter the religious other in interreligious education or interreligious collaboration and to learn from the other.

- Another stimulus that can be inferred from the Islamic understanding of education is the perception of education as a comprehensive task. The Qur'an describes the human being not only as a creature capable of learning but also as able to appropriate knowledge and to reflect on it. Education is thus accorded a central role in equipping people to do justice to their responsibility to creation, and not least of all to be able to be cognisant of their individual responsibility for their decisions and actions. According to the Qur'an, human beings are encouraged to investigate their environment, to acquire new insights and take various perspectives into consideration. With respect to religious education, these objectives can be attained only if doubt or criticism is permitted in the educational process and an encounter with other religions and learning from and with those of other faiths is taken into account. It is especially through interreligious collaboration or interreligious learning that an Islamic religious educational approach can do full justice to the principle of education as a comprehensive task. 
- A final aspect is concerned with the relation to other individuals. From the Islamic perspective, education is always to be understood as relational. Human beings do not educate themselves alone and only for themselves but in exchange with others and with the goal of being able to act and decide in responsibility for others as well or for the entrusted creation. The inalienable dignity of all people indicates, moreover, that a claim to superiority towards people of other faiths is out of place. It can be concluded here that the objective is that human beings should develop a basic attitude as a result of educational processes, that humans can be different from each other, that we can acknowledge what is other, understand religious plurality as the norm, and develop the willingness to learn from the religious other. To attain this objective, human beings are encouraged to go through interreligious learning processes and to engage in discussion with the religious other. Only by stepping outside, only by opening up, taking the risk, in the encounter and relation with others or those of other faiths and leaving one's own shore can such an understanding of education be fulfilled (Kraml, 2003; Sejdini, 2016a).

\section{Conclusion}

The goal of this essay was to contribute to existing interreligious approaches in the confessional context. It was argued that educational perspectives or those of the education sciences play a dominant role, whereas anthropological foundations of the religious communities involved do not receive sufficient attention. This concerns especially Islamic perspectives. Because of this, this essay focused on the analysis of central basic assumptions of Islamic anthropology (such as the createdness and dignity of human beings, freedom, and responsibility, as well as reason and the ability to learn), and those of the Islamic understanding of theology and education.

The existing instances of interreligious collaboration and approaches to interreligious learning should be encouraged to include Islamic perspectives in a more conceptual way in the sense of a dialogue between equals. This can happen in interreligious education in the form of various implications that can be drawn from anthropological, theological, and educational foundations.

In this way, interreligious collaboration and approaches to interreligious dialogue can be supported in promoting recognition and respect of other religions and people of other faiths (Sejdini, 2017a, 176). This is, however, not an easy undertaking, even if it is urgently necessary. A respect for religious plurality based on theology and religious educationally is made difficult by the latent truth 
claim that religions raise in one form or another. In line with the anthropological foundation of human freedom, a possible way out of this difficulty may be to point out that faith is to be understood as a personal experience. As a personal experience that people have to take a pursue in accordance with their own convictions, without fear of any consequences whatsoever. This approach forms the key to a respectful attitude towards the other in a multicultural and multireligious democratic society. 